VOLODYMYR SERHIYCHUK,

Taras Shevchenko National University of Kyiv (Kyiv, Ukraine)

e-mail:serhijchuk@ukr.net, ORCID 0000-0002-4053-1733

\title{
DETERMINING THE NUMBER OF VICTIMS OF THE HOLODOMOR GENOCIDE OF 1932-1933 IN UKRAINE
}

The article analyzes the state of counting the casualties of the Holodomor-genocide of 19321933 in Ukraine. In par-ticular, there are testimonies of German and Italian diplomats of the time, who received confidential information from Soviet officials, which formed the basis of the established diaspora statement about the casualties: "from 7 to 10 million". It is noted that during Gorbachev's Perestroika in the USSR, Moscow was forced to recognize the Holodomor in Ukraine and allowed to write about the loss of 3.5 million people. Modern Ukrainian demographers, who work for foreign grants, continue to support this figure with some clarifications. At the same time, the primary documents of the Ukrainian archives, thanks to the historical and statistical method, make it possible to establish the minimum number of casualties during the Holodomor-genocide of 1932-1933 at 7,117.6 thousand people, because the information has been perceived on the population of the UkrSSR as of early 1932 (32,680 thousand people) and those born in 1932-1933, which allows us to establish the presence of inhabitants of the city and village as of January 1, 1934 using updated materials of the All-Union Census of 1937 and human growth in 1934-1936 only 26,815.8 thousand. And it should have been 33,853.5 thousand people. And the use of historical-statistical method of calculation allows to reach the figure of 9.5 million in the UkrSSR. This is provided that the dead hungry Ukrainian peasants in Russia and Belarus, where they went for bread, and were shot by Soviet border guards or drowned in the Zbruch and the Dniester due to their inability to swim are counted; when the number of workers brought from the Soviet republics in 1932-1936 to the socialist new buildings of the UkrSSR, who were counted as its inhabitants during the All-Union census of 1937, etc., are established.

Of particular importance for establishing the probability of these losses is the reconstruction of the correspondence of the occupancy of the first grades of Ukrainian schools in 1932-1939 with the number of births in 1924-1931. Thus, in the Orativ, Tarashchansky, and Pereyaslavsky districts of the then Kyiv Region, after 1933, half or even less of 8-year-old children were admitted to school. The same picture was observed in all areas of the current Poltava Region. As in all primary schools in the Petrykivka district of the Dnipropetrovsk Region, where almost half of last year's students of 1st-3rd grades, who continued their education from September 1, 1933, were not admitted $-1,883$.

This comprehensive approach to the study has made it possible to establish the loss of children, which was not less than 4 million, and the total losses in the UkrSSR, using the historical and legal method, - more than 9 million people. More than 1 million losses of Ukrainians outside the UkrSSR should be added to these victims, which is a total of more than 10 million.

Keywords: Holodomor genocide of Ukrainians in 1932-1933; historical-statistical calculations and demographic cal-culations of real losses.

\section{Introduction}

With the recognition of the Holodomor of 1932-1933 as genocide of the Ukrainian people, the attention of researchers to determining the number of casualties of this national tragedy has inctreased. Therefore, the purpose of the article is to analyze published studies on this subject and, having evaluated the original documents from the former secret archives, as well as eyewitness accounts, to propose new approaches to determining the number of casualties, taking into account the full range of sources and new methods of scientific research available to scientists.

The research methodology is based on the principles of historicism. In addition to the historical-system method, critical analysis of sources, problem-chronological, typological methods have been used, as well as synthesis and generalization. The author proposes the use of historical-statistical method, when the analysis of available documents on population in different periods allows to obtain the necessary data by arithmetic calculation, which determines the minimum casualties. In addition, given the deliberate destruction of the main array of statistical documents of the prewar period by the Bolshevik authorities, the author proposes to apply the historicaldemographic method of calculating all victims of the Holodomor genocide of 1932-1933 through a comparative analysis of fullness of primary school in 1932-1939, in 
particular, of the first grades, with the number of births in the respective years.

\section{Results and discussion}

The problem of casualties during the Holodomor genocide in Ukraine in 1932-1933 arose at that time, primarily in the reports of foreign diplomats accredited to the USSR. For example, the Consulate General of Germany in Kharkov reported on December 11, 1933: "It is known from reliable sources that, according to official estimates, seven million victims do not represent a great loss, but this means that a quarter of the peasantry was destroyed, which is a terrible number even compared to the victims of World War II" (Holodomor v Ukrayini, 2008: 161).

And Schiller, an employee of the German Embassy in the Soviet Union, added: "In my opinion, the above figure of 10 million victims of famine is not an exaggeration" (Holodomor v Ukrayini, 2008: 130).

These figures were constantly used by the Ukrainian diaspora when it began to honor the victims of the Holodomor. For example, on August 2, 1953, a demonstration was held in Manchester, Great Britain, under the slogan "We blame Moscow for the deaths of seven million Ukrainians killed by the famine of 1933 ". 1

It is clear that in the USSR, any mention of the Holodomor of 1932-1933 was forbidden, so there were no figures concerning its victims. Only with the beginning of Gorbachev's Perestroika it was allowed to write about it, presenting it as a tragedy of all the peoples of the Soviet Union. Thus, the director of the Central State Archives of the USSR V. Tsaplin writes that the high mortality rate in 1933 is directly related to Ukraine, because "according to the UkrSSR data, the number of deaths was 2.9 million people, i.e. more than half of those who starved to death in the USSR, meanwhile, when the population of Ukraine is only one-fifth of the population of the USSR" (Tsaplin, 1989: 180).

At the same time, this author notes that 3.8 million people were not registered in the civil registry during this period (Ibid: 178). Apparently, therefore, in those years in the Central Department of National Accounting of the State Plan of the USSR "two calculations of natural population increase were purposefully carried out: one for the press, the other for official use" (Ibid).

As for Ukrainian researchers, even in 1988 they protested against the meetings of the International Commission of Jurists, which considered this issue in Brussels and New York, trying to prove that "there was no famine", and already at the time of independence they, as "the most prepared", began to acknowledge this tragedy, repenting for their Soviet improvidence. The championship here was held by Professor Stanislaw Kulczycki, who constantly repeated the figure of $3,238,000$ people allowed since communist times, which he considered to be a direct loss from the 1933 famine. In addition, he added 144 thousand losses in 1932 (Kulchytskyy, 1991: $355,356)$.

Later, associating itself with modern Ukrainian demographers, he moved to their position on the loss of 3.9 million and persistently promoted this figure in the submission to the UN, because it allegedly helped the world to recognize the Holodomor of 1932-1933 as genocide. At the same time, his argument, as well as that of

\footnotetext{
${ }^{1}$ Ukrainski visti (Novyi UIm). 1953. 22 zhovtnia (Ukrainian News (New UIm). 1953. October 22).
}

our demographers, seems rather strange: since the number of losses of 3.9 million is already known in the world, let us accept it completely. Moreover, as is said, even the factual basis of publications by well-known foreign authors "was formed in collaboration with Ukrainian scholars and Ukrainian culture scientists of the United States and Canada" (Serhiychuk, 2020: 491).

Modern foreign researchers, as a rule, repeat the arguments of S. Kulchytsky. In fact, only one of them tries to declare the figure of 3.8 million deaths by referring to the postulates of demographic science. In particular, Oleg Volovyna, an employee of the Center for Slavic, Eurasian and East European Studies at the University of North Carolina at Chapel Hill, published his article "Terror by famine: how to scientifically justify the number of victims?" (Volovyna, 2018).

It was $O$. Volovyna who created the UkrainianAmerican group, which, working on foreign grants organized by him, tried to establish this figure as the final number of victims of the Holodomor genocide of 19321933. Members of this group, in particular, state: "Between 1932 and 1933, about 8.7 million deaths in the USSR were caused by famine. Almost $98 \%$ of these casualties were in the three Soviet republics: Ukraine (3.9 million), Russia (3.3 million) and Kazakhstan (1.3 million). If we calculate the relative losses, i.e. losses per thousand of population, Ukraine is second after Kazakhstan. Hunger losses account for $22 \%$ of the total population of Kazakhstan, $17 \%$ in Ukraine, $3 \%$ in Russia and less than $2 \%$ in other republics of the former USSR" (Levchuk et all, 2015: 87).

Unfortunately, these authors do not show the sequence of their calculations, and the sharp decline in the population of Ukraine is explained mainly by its intensive migration outside the UkrSSR, which is not confirmed by available documents. Thus, the mechanical movement of the population of the Kharkiv Region outside the UkrSSR in 1932-1936 has the following results (Table 1):

Table 1. - Population movement of the Kharkiv Region outside the UkrSSR in 1932-1936 ${ }^{2}$

\begin{tabular}{|l|l|l|l|l|}
\hline Migration area & \multicolumn{4}{|c|}{ Ariived / departed } \\
\hline & \multicolumn{1}{|c|}{1932} & \multicolumn{1}{|c|}{1934} & \multicolumn{1}{c|}{1935} & 1936 \\
\hline The RSFSR & $92485 /$ & $71880 /$ & $75102 /$ & $101727 /$ \\
& 73206 & 57053 & 70715 & 79157 \\
\hline The BSSR & $2705 /$ & $1921 /$ & $2778 /$ & $2720 /$ \\
& 2216 & 1717 & 2685 & 2388 \\
\hline $\begin{array}{l}\text { The Azerbai- } \\
\text { jan SSR }\end{array}$ & $899 /$ & $599 / 616$ & $1321 /$ & $1381 /$ \\
\hline The Armenian & 792 & & 855 & 1516 \\
SSR & $95 / 60$ & $152 / 141$ & $372 /$ & $489 / 393$ \\
\hline The Georgian & $1155 /$ & $1281 /$ & $1613 /$ & $1609 /$ \\
SSR & 926 & 1030 & 1191 & 1349 \\
\hline $\begin{array}{l}\text { The Uzbek } \\
\text { SSR }\end{array}$ & $443 /$ & $435 / 312$ & $582 /$ & $639 / 630$ \\
\hline The Tajik SSR & 369 & & 463 & \\
\hline $\begin{array}{l}\text { The Turkmen } \\
\text { SSR }\end{array}$ & $189 /$ & $97 / 37$ & $176 /$ & $146 / 102$ \\
\hline & $926^{3}$ & $112 / 138$ & $322 /$ & $441 / 284$ \\
\hline
\end{tabular}

\footnotetext{
${ }^{2}$ State Archives of Kharkiv Region. Fund P-5231. File 2. List 2. Page I. 5, 5 (rev.); File 10. List I. Page 1-1 (rev).; File 18. List I. Page 7, 7 (rev); File 27. List I. Page 7, 7 (rev).

${ }^{3}$ It is, obviously, about return of a part of the so-called "bais" which were sent to the southern areas of the USSR for introduction of cotton.
}

SKHID Vol. 2 (2) July-August 2021 
It should be added that Ukrainian peasants who rushed to the city to get a job in order to save their families from starvation were not taken into account, because labor would be sought on the sidelines. For example, on January 8, 1932, Khudokormov, a member of the People's Commissariat for Labour, reported to the Council of People's Commissars of the Ukrainian SSR that in 1932 , an additional 600,000 people were needed to provide industry and construction with labor, including 130,000 for the Donbass mines. For the latter, it was planned to recruit 44,000 from the UkrSSR and 64,000 from the RSFSR. ${ }^{4}$

The need for 130 thousand skilled workers was planned to be covered by economic training of 70 thousand, as well as by recruiting 20 thousand from the regions of the UkrSSR and 40 thousand - from the RSFSR. $^{5}$

The recruitment plan for the "Stalinugol" for MarchMay 1932 provided for: 6,575, including 2,375 from the UkrSSR, 800 from the Central Committee, 2,500 from Tatarstan, and 900 from the BSSR. ${ }^{6}$

The tradition of importing labor from outside the UkrSSR gained special development with the beginning of the Holodomor. According to the documents, "the most stable were the groups recruited from the Western Region and the Tatarstan Republic... In terms of the implementation of the plan, Ukraine was the last".

On this occasion, on January 23, 1932, Kosior was informed: "Now we are witnessing the following picture: old miners from Belarus and the Central Black Earth Region, who have settled in the village in recent years, untie the "anchor" with all their belongings, families and matchmakers and move to Donbass, and seem to settle in Donbass seriously and permanently".

Naturally, this was noted and on April 10, 1932, members and candidates for members of the Political Bureau of the Central Committee of the $\mathrm{CP}(\mathrm{b}) \mathrm{U}$ considered a note on the need "to replenish the loss in the labor force, make a new recruitment of labor for the Donbass in the amount of 20 thousand people. Of these, 10 thousand should be recruited within Ukraine, and the remaining 10 thousand - within the RSFSR, the Central Committee of the CPSU (b) should be asked for this". 9

This tendency - to recruit anything outside the UkrSSR - was supported at the grass-roots level. Thus, the leaders of the Chemical Plant named after H.I. Petrovsky, which in August 1932 lacked 2,795 workers, asked the higher authorities to "to allocate other areas in Ukraine, obliging regional organizations to ensure the let people from collective farms, and to raise a question before the Central Committee of the Communist Party of the Soviet Union and the People's Commissariat for Labor on the allocation of areas in the RSFSR and the Byelorussian SSR for an organized recruitment of labor force". ${ }^{10}$

At the same time, such a phenomenon as the self-flow of labor became widespread, including from outside the

\footnotetext{
${ }^{4}$ The Central State Archives of Supreme Bodies of Power and Government of Ukraine. Fund 539. Desc. 10. File 73. Page 24

${ }^{5}$ Ibid. Page 25.

${ }^{6}$ The Central State Archives of Public Organizations of Ukraine.

Fund 1. Desc.20. File 5315. Page 16.

${ }^{7}$ Ibid. File 5588. Page 5.

8 Ibid. Page 9.

9 Ibid. File 5313. Page 84.

${ }^{10}$ Ibid. File 5326. Page 8, 9.
}

UkrSSR, and at other large enterprises. For example, in the first eight months of 1932, 7,849 workers came to the construction of "Azovstal" due to self-flow, and only 3,002 were recruited. ${ }^{11}$

Recruitment of labor from outside the UkrSSR was in the first place and the participants in a special meeting on "streamlining the case of recruiting workers for the coal industry of Donbass" at the Donetsk Regional Committee of the CP(b)U in January 1933, which invited "representatives of NKTrud USSR and Ukrainian SSR, Glavtop, coal trusts of Donbass and their representatives from regions, representatives of regional committee of $\mathrm{TsCO}$, Belarus, Tatarstan, Kyiv region, Vinnytsia...."12

Local "Moscow watchers" were instructed to take the initiative in this regard. Thus, on August 4, 1933, Khazanov, secretary of the Dnipropetrovsk regional committee, asked Kaganovich and Kosior to "allocate additional limits on the import of skilled and unskilled labor from other regions and republics of the Union in the amount of up to 36,000 people (preferably from the Tatar, Bashkir and Belarusian republics)". ${ }^{13}$

And on July 24, 1933, the bureau of the Regional Committee decided: "Considering that the intraregional labor resources cannot cover all the needs of factories and new buildings in the region, to ask the Central Committee of the Communist Party of the Soviet Union, the Central Committee of the Communist Party of Ukraine and the People's Commissariat of Heavy Industry to provide the factories and new buildings of our region, and primarily the factories of Petrovsky and Dzerzhinsky, with labor from other regions and territories of the Union, in order for the People's Commissariat for Labor to attach Tatarstan and Bashkiria for recruitment and allocate additional limits for qualified and unqualified labor force". ${ }^{14}$

On September 25, 1933, the same secretary of the Dnipropetrovsk Regional Committee of the Communist Party, Khazanov, informing Kaganovich and Postyshev that up to 25,000 recruited collective farmers from the Middle Volga were working on the region's construction sites, asked to be allowed to "use the money they earned to buy grain in an organized manner during the period of permission for free trade of grain". ${ }^{15}$

Three weeks later, the Dnipropetrovsk Regional Committee asked Kaganovich to allow "allocating additional limits on the import of labor of 36,000 people into the region, preferably from the Tatar, Bashkir and Belarusian republics". ${ }^{16}$ And on November 3, 1933, the bureau considered the issue of preparation for the acceptance of the recruited labor force by factories on the Middle Volga. Concerns were expressed that Dniprokombinat had not mastered the recruitment orders for 12,000 workers in this Russian region, the plants named after Dzerzhinsky and Petrovsky, the Dzerzhinskbud trust - for 2,000 each, the "Ruda" trust and Kryvbasbud - for 4,000 each. Nikopolbud (order for 1,000 workers), Kryvyi Rih-CokeChemical Installation (1,000), and Zaporizhia-Coco-

\footnotetext{
${ }^{11}$ lbid. File 5599. Page 5.

12 lbid. File 6237. Page 33.

13 Ibid. File 6241. Page 31.

14 State Archives of Dnipropetrovsk Region. Fund P-19. Desc. 1. File 525. Page 49 (rev).

${ }^{15}$ The Central State Archives of Public Organizations of Ukraine. Fund 1. Desc. 20. File 6243. Page 71.

${ }^{16}$ Ibid. File 6241. Page 33.
} 
Chemical Construction (2000) also unsatisfactorily mastered additional funds in the Samara Region. ${ }^{17}$

This issue, apparently, was under control in the Kremlin, because on July 5, 1932, Stalin's assistant Bazhanov telegraphed Kosior to "mobilize 25,000 people in August, 29,000 people in September (in Tatarstan, Black Earth, Belarus, Ukraine and the Western Regions)". ${ }^{18}$

Thus, people tried to obey the orders of Moscow locally in the Russian hinterland. For example, the secretary of the regional committee of the Central Black Earth Region Malinov telegraphed to the secretary of the Central Committee of the Communist Party of Ukraine Terekhov: "Influence the coal trusts of Ukraine to immediately transfer money to the authorized person of Voronezh Glavtop to send recruited workers, stop". ${ }^{19}$

Of course, such "tips" from Russia immediately prompted the leaders of Ukraine's industrial enterprises to take active action: in December 1932, the "Stalinugol" sent 516 recruiters, of whom only 40 were from Ukraine. ${ }^{20}$

The following fact is also eloquent: in October 1932, 859 people were hired at the "Kadyivvuhilya" trust mine, of which only 123 were from the UkrSSR. ${ }^{21}$

It is undeniable that in order to determine the casualties during the Holodomor genocide, it is necessary to know two indicators: the population of the UkrSSR as of January 1, 1932 and in 1934. In our opinion, in this situation it is necessary to take as a basis the then census of the population as of January 1,1932, as we have indicators of the presence of inhabitants of both the village and the city at that date. In each of the 8 handbooks on basic statistical and economic indicators of the economy of the districts of the respective oblasts and the Autonomous MSSR issued in Kharkiv by the Department of Affairs of the Council of People's Commissars of the Ukrainian SSR, the first section "Territory and Population" is accompanied by a special explanatory notes for the tables: "Information on the territory and population was compiled as of January 1, 1932 on the basis of the materials of the Central Administrative-Territorial Commission at the AllUkrainian Central Executive Committee, which were received from the district executive committees" (Dovidnyk z osnovnykh statystychno-ekonomichnykh pokaznykiv..., 1933: 5).

In general, the population of the USSR at that time, according to them, numbered $32,680.7$ thousand people: urban population $-7,127.7$ thousand, rural population 25,553.0 thousand. $^{22}$

As for the data on January 1, 1934, it can be calculated on the basis of existing documents: if we add to the official population of $32,600.7$ thousand people of the UkrSSR as of January 1, $19321,212.7$ thousand births in these two years, then on January there should have been 1, $193433,853.5$ thousand.

How do we determine the real number? The official data of the All-Union Census of 1937, which the Bolshevik authorities published only in 1990 , showed the num-

\footnotetext{
17 State Archives of Dnipropetrovsk Region. Fund П-19. Desc 1. File 529. Page 123 (rev.)

${ }^{18}$ The Central State Archives of Public Organizations of Ukraine. Fund 1. Desc. 20. File 5315. Page 91.

${ }^{19}$ lbid. Page 105.

20 lbid. Page 120.

21 Ibid. Page 42, 43.

22 Ibid. Page 8
}

ISSN 1728-9343 (Print)

ISSN 2411-3093 (Online) ber of inhabitants of the UkrSSR at 28,383.0 thousand. At the same time, the recalculation of the district census results showed that this figure was overestimated by at least 532 thousand people. That is, in fact it turned out to be $27,854.9$ thousand. If we deduct the increase for 1934-1936 (1934 - 88.2 thousand people, 1935 417.2 thousand, 1936 - 533.7 thousand - only $1,039.1$ thousand) from this figure, then as of January 1 , 1934 we have only 26,815.8 thousand inhabitants. And deducting this figure from the real as of January 1, 1934 $\mathbf{3 3}, \mathbf{8 5 3 . 5}$ thousand, we obtain the total number of deaths in 1932-1933: 7,117.6 thousand people.

And this is not about possible natural population losses in 1932-1933. After all, it is not known whether Jews counted their losses during the Holocaust separately as natural and violent. At least, I do not know of a part of the 6 million victims, what they consider as the ultrahigh mortality that our demographers introduced to calculate the losses of Ukrainians in 1932-1933. And a wellknown expert in this matter, Andriy Kozytskyi from Lviv, clearly points out that "the term "ultrahigh mortality" is categorically used neither in relation to the Holocaust, the Armenian genocide and the genocide of Gypsies, nor in the scientific community of any country, among politicians, publicists or public figures" (Quoted in: Serhiychuk, 2021: URL).

However, in order to establish a specific figure by carefully examining all the circumstances of this tragedy, in our opinion, it is necessary to continue a purposeful search that will add many unaccounted victims to this minimum number. And it is not only about those who died of starvation on Ukrainian chernozem, but also about the victims of the Holodomor.

This refers to thousands of hungry Ukrainian peasants who tried to reach Poland and Romania through the swamps of Polissya, the Zbruch and the Dniester, but were shot by Soviet border guards, or did not reach the rescue shore, where they hoped to get the desired bread. Why in some regions it was forbidden to write about children who died before 1 year at a registry office? And why did they stop drawing up death certificates there after March 1933? (Kovalenko, Manyak, 1991: 49-50).

And are the deaths of all those children who were put into orphanages, but did not wait for help, because no one opened the door for the crying baby, taken into account? It is even frightening to remind of another underestimation of the victims of the Holodomor - unknown children-beggars who got lost in the search for foodstuff, who were lured by cannibals and killed. And there were beggars from distant villages who died just on the road who recorded the death of an unknown person? Naturally, no one identified or counted the number of dead on the roads, the corpses of which were taken away by wild dogs...

And it also happened when the deceased was taken to the cellar and thrown in the trash, or whole families, like brothers Ivan and Franko Kuryativ from the village of Denyshi in the current Zhytomyr Region, were dumped in a well, which was covered with earth.

No one counted the graves that were dug in the gardens, where the whole family died, as it was in Piskivka near Krasnograd, in the Kharkiv Region. In this extinct village, no one knew about those who died in their houses until the spring, until people from Krasnograd came to

SKHID Vol. 2 (2) July-August 2021 
work in the spring. Only then, the already unrecognizable people were buried... (Kovalenko, Manyak, 1991: 320, $343,535,84,313,507,508)$.

As the guard of the Krasnograd city cemetery testified, "this was happening to us then! Half the people died. And these villages that are behind Berestova (the river in Krasnograd) - if at least one living soul remained in them... Chumak fails to transport them, and we fail to dig holes. And people cannot stay alive as they came: in leather jackets, belted, with revolvers. They pull from the pantry, sweep from the attic, and snatch from the cellar. Potatoes, beets, beans, dried pears - all is swept. I don't even talk about bread. The snow hasn't fallen yet, and people are already starving...

A pit could not be dug in winter, so Chumak took people to Berestova on a precipice. These were the ones who fell in the middle of the street. And how many were on the roadside, in the weeds! As the earth had steamed, there was nothing to breathe..." (Kovalenko, Manyak, 1991: 507).

It was similar in other regions of Ukraine. For example, here is what P. Sviridov from Novorozsosha of the Novopskovsky District of the current Luhansk Region testified: "Didn't have time to dig holes. Then it was not possible to dig a grave at all... People were buried as possible. They simply could not reach the cemetery. More were buried in gardens, yards, cellars. People died everywhere. From there they were taken and without shouting they immediately were buried in a hole somewhere and covered with earth. I remember my sister being buried in the cellar and my mother in the garden. Nobody asked about anyone - neither the authorities nor relatives. Everyone was waiting for nothing but death". ${ }^{23}$

On September 29, 1973, Vasyl Horbachuk, a teacher at the Slavic Pedagogical Institute, told a migrant to the Donbass from the Belgorod Region: "The neighboring village of Bogdanovka, what gardens were there! - completely starved to death in the 33rd. My wife and I went to visit relatives in May. It was terrible: there were dead men in gardens, as it happened, small children, there was no one to bury. The first ones were thrown into the pit, and then fell where death occurred. There was no one to bury, none of the relatives survived..." (Horbachuk, 2010: 6).

And is not it the most important thing: who calculated how many workers from Russia and other Soviet republics were brought to Ukrainian cities? After all, in the 1937 census, which showed a decrease in the population of the UkrSSR compared to 1926 , they actually took the place of those whom Ukraine lost during this period, including those born before 1932 .

And how to take into account the Ukrainians who died in the North, who according to the resolution of the Central Committee of the CPSU (b) of March 8, 1933 were to be taken from prisons in the UkrSSR to ODPU special camps in the amount of 40 thousand people, "regardless of physical condition and age"? (Holodomor 1932 1933 rokiv v Ukrayini, 2007: 737).

Where should we put the victims of the category of "criminals" who were driven to build canals, where they, exhausted by hunger and overwork, died quickly? Or socalled kulaks, expelled for non-fulfillment of unbearable grain supplies, whose children began to die en masse in the harsh North? (Kovalenko, Manyak, 1991: 423).

\footnotetext{
${ }^{23}$ Peremoga (Novopskov). 1993. September 17.
}

Should they be classified as the organized relocation to the "new buildings" of socialism? Putting their heads in the taiga, are they already Russia's casualties? Is not this Ukraine's loss from the Holodomor? Should they be classified as unorganized migrants? No! These are the casualties caused by the Holodomor, that should be included in the register of the Ukrainian nation!

We cannot distance ourselves from the losses of those Ukrainians who declared their national identity outside the UkrSSR - only in the Russian Federation, according to the 1926 census, there were about 7 million of them. And in 1937 this figure decreased to $3,087,022$, although it is clear that Ukrainians continued to be born in all areas of their settlement outside the UkrSSR during this historical period. Where then did they disappear?

One of the Russian government statisticians, Kurman, testified directly: "A number of special field visits showed that in Ukraine, the Azov-Black Sea region, the Saratov and Stalingrad regions, the Kursk and Voronezh regions, there were a significant number of deaths not recorded in the registry offices..." (Tsaplin, 1989: 178).

But it was in these regions of Russia at that time that Ukrainians declared themselves en masse, as evidenced by the All-Union Census of 1926. And we still do not have specific data on the losses from starvation of Ukrainians in the Kuban, Central Black Earth Region, the Volga Region (especially the Lower Volga Region, where Stalin extended the ban on bread at the request of the local regional party in February 1933), Kazakhstan.

How many of them died of starvation, and how many people refused to call themselves and their children Ukrainians under the influence of his horrors and repressions for belonging to Ukrainians?

The number of Ukrainians increased only in places of exile: in Karelia by 30 times (from 700 to 22 thousand), in the Krasnoyarsk Krai - by 3.5 times (respectively 15 thousand and 52 thousand), in Novosibirsk - by 2, 5 times (60 and 141 thousand), in the Chelyabinsk Region - more than by 5 times (12 and 73 thousand), in Chita from 7 to 38 thousand. And in Sverdlovsk in 1926, Ukrainians were not even recorded in the census, and in 1937 - they numbered 53 thousand (Zhiromskaya, 2001: 85).

The fact that the losses of Ukrainians could indeed reach more than 10 million, as foreign diplomats emphasized, is confirmed by a careful study of the occupancy of primary grades, especially the first grades, of then Ukrainian school. In particular, the following circumstance draws special attention: if in the 1930-1931 school year $1,102,843$ students came to the first grade, then the same number with a small decrease (up to $2 \%$ ) was to study in the 1931-1932 school year in the 2nd grade, in 19321933 - in the 3rd, and in 1933-1934 - in the 4th. However, according to the directory "Education in Ukraine", only 674,311 students studied in the 4th grade at that time, and not at least 1 million. Thus the loss of first-graders in 1930, and fourth-graders in 1934 amounted to more than 325 thousand!

Another inconsistency of Soviet statistics after the Holodomor was as follows: if $1,162,852$ children were born in the UkrSSR in 1924, then, taking into account natural losses, in 1932, 1 million students were to come to the first grade. This number was supposed to go to the 2nd grade in the 1933-1934 school year, but only 798,305 came. That is, there was more than 200,000 shortages of 
another age group of children, if we take into account even the statistics of the Bolshevik government, which has already sinned by its distortions.

And the problem with the occupancy of school classrooms really worsened in the fall of 1933. Ivanyuk, the former director of a junior secondary school in the Poltava Region, testified that out of 225 students, only 109 children came to classes on September 1, 1932, in the spring of $1933 .^{24}$

Approximately the same indicators of a shortage of schoolchildren were in September 1933 in the Petrykiv district of Dnipropetrovsk region. The comparative table of the number of students only in primary schools in this area according to the updated data looks like this (Table 2).

Table 2. - Comparative table of the number of primary school students in Petrykivka District of Dnipropetrovsk Region

\begin{tabular}{|c|c|c|l|l|l|}
\hline Years & $\begin{array}{c}\text { 1st } \\
\text { grade }\end{array}$ & $\begin{array}{c}\text { 2nd } \\
\text { grade }\end{array}$ & $\begin{array}{c}\text { 3rd } \\
\text { grade }\end{array}$ & $\begin{array}{c}\text { 4th } \\
\text { grade }\end{array}$ & Total \\
\hline 1932 & 1737 & 1275 & 1126 & 1121 & 5259 \\
\hline 1933 & 1254 & 867 & 695 & 693 & 3509 \\
\hline
\end{tabular}

In this area, as can be seen from the table, on September 1,1933 , there were 1,750 fewer students in primary school than a year before. ${ }^{25}$

But the numbers are even more staggering when it comes to those who continued their studies in 1933, moving from the 1st to the 2nd grade, from the 2nd to the 3rd, and from the $3 \mathrm{rd}$ to the $4 \mathrm{th}$, respectively. Only in 3 grades, already 1,883 appear to be missing. And this is taking into account the fact that we do not know how many children had to come to the 1st grade in 1933 and how many fourth-graders of the 1932 enrollment survived as of June 30, 1933.

Problems also arose with the occupancy of the primary grades of the suburban Dnipropetrovsk Region, where many parents worked at the city's industrial enterprises, thus receiving a stable food supply, which was a lifeline for the family. If, for example, on September 1, 1932, 12,834 children came to these groups, then on June 30 , 1933 , that is, at the end of the school year, only 11,214 remained. The difference in the numbers of students was 1,620. And they could not all go to study in the city schools of Dnipropetrovsk, because the primary grades there had decreased by 833 students from September 1 , 1932 to June $30,1933 .^{26}$

In some districts of the then Kyiv Region (now Vinnytsia, Zhytomyr, Kirovohrad and Cherkasy) documents on enrollment in the 1st grade in 1931 have been preserved, which made it possible to compare it with the number of those who came to the same schools in the fourth grade in 1934-1935 school year. Unfortunately, the relevant documents have survived only in some areas, although they give an idea of the picture of the loss of first-graders in 1931 (Table 3).

\footnotetext{
${ }^{24}$ Ukrainski visti (Novyi Ulm). 1953. 22 zhovtnia (Ukrainian News (New Ulm). 1953. October 22).

${ }^{25}$ State Archives of Dnipropetrovsk Region. Fund P-19. Desc. 1. File 483. Page 154.

${ }^{26}$ Ibid. Fund 439. Desc 1. File 12. Page 141.
}

ISSN 1728-9343 (Print)

ISSN 2411-3093 (Online)
Table 3. - Comparative table of the number of students enrolled in 1931 in some districts of Kyiv Region (data for September 1934) ${ }^{27}$

\begin{tabular}{|l|c|c|}
\hline \multicolumn{1}{|c|}{$\begin{array}{c}\text { Name of the } \\
\text { District }\end{array}$} & $\begin{array}{c}1931 \\
\text { (1st grade) }\end{array}$ & $\begin{array}{c}1934 \\
\text { (4th grade) }\end{array}$ \\
\hline Boryspil & 2250 & 1590 \\
\hline Vasylkivsky & 2859 & 1699 \\
\hline Volodarsky & 1607 & 1018 \\
\hline Yemilchynsky & 2688 & 1610 \\
\hline Zvenigorodsky & 1913 & 1395 \\
\hline Luhynsky & 1780 & 837 \\
\hline Makarivsky & 1958 & 1230 \\
\hline Malinsky & 3136 & 1705 \\
\hline Plyskivsky & 2118 & 1296 \\
\hline Rzhyshchivsky & 2249 & 1348 \\
\hline Radomyshl & 2192 & 1180 \\
\hline Fastivsky & 2682 & 1641 \\
\hline
\end{tabular}

The same was observed in the coming years. Thus, in the Orativ District, which now belongs to the Vinnytsia Region, we see such a picture with the occupancy of primary grade in the 1935-1936 school year, especially eight-year-olds, who were born in 1927 and came to primary (p), junior secondary (js) and secondary (s) schools ( ${ }^{*}$ - incomplete data). Approximately the same number of children were born in 1924, who then came to 1st grade in 1932 at the age of 8 . But by the end of this school year, not all of them had survived, because as of June 10, 1933, the picture was completely bleak (Table 4).

We should also take into account that the peak of deaths then was attained in late June - early July. And no one counted how many students died before September 1. For example, in Stadnytsia (now part of the Kyiv Region) in April 1933, only 7 children under 14 years of age were officially recorded, in May - 21, in June - 18, in July -34 , and in August - 5. The document on report of the Medov Junior Secondary School for the 1932-1933 school year draws attention: only 8 eight-year-old children were able to live to June 10, 1933, although in 1924 there were 105 of them born in this village. A similar picture was in Lopatyntsi and Khmelova, where only three of yesterday's first-graders stayed alive at that date. ${ }^{28}$ Probably, a few natives of 1924 were in high school.

We have the opportunity to compare the consequences of admitting children to the first grade in the next year. Thus, in the Tarashchansky District of the Kyiv Region as of September 15, 1936, the situation was as follows (Table 5).

The calculations of the State Planning Committee of the UkrSSR of September 15, 1931 were in deep contradiction with the actual number of children who were to come to the first grade on September 1, 1938 throughout Ukraine. The last, born in 1930 (then 1,022,952 babies were born), should have been at least 780 thousand, as was supposed seven years before ${ }^{29}$, and according to the statistical department of the People's Commissariat of

\footnotetext{
27 The Central State Archives of Supreme Bodies of Power and Government of Ukraine. Fund 166. Desc. 11. File356; State Archives of Kyiv Region. Fund P-144. Desc. 1. File 1765.

${ }^{28}$ State Archives of Kyiv Region. Fund 5634. Desc.1. File D. $1275,1276$.

${ }^{29}$ The Central State Archives of Supreme Bodies of Power and Government of Ukraine. Fund 166. Desc. 10. File 1038. Page 4
} 
Table 4. - Comparative table of first-graders of Orativ District in 1932-1933 school year to the number of births in 1924, as well as births in 1927, enrolled in the first grade in September $1935 .^{30}$

\begin{tabular}{|c|c|c|c|c|c|c|c|}
\hline Name of the school & $\begin{array}{c}\text { Born in } \\
1924\end{array}$ & $\begin{array}{c}\text { Came to } \\
\text { 1st grade in } \\
\text { September } \\
1932\end{array}$ & $\begin{array}{c}\text { Remained } \\
\text { as of } \\
\text { June } 10 \\
1933\end{array}$ & $\begin{array}{l}\text { Including } \\
\text { 8-year-old }\end{array}$ & $\begin{array}{c}\text { Born in } \\
1927\end{array}$ & $\begin{array}{c}\text { Came to } \\
\text { 1st grade in } \\
\text { September } \\
1935\end{array}$ & $\begin{array}{l}\text { Including } \\
\text { 8-year-old }\end{array}$ \\
\hline $\begin{array}{l}\text { Orativska js } \\
\text { Orativska p }\end{array}$ & 120 & $\begin{array}{l}90 \\
13\end{array}$ & $\begin{array}{l}71 \\
12\end{array}$ & $\begin{array}{l}50 \\
10\end{array}$ & 139 & $\begin{array}{l}81 \\
10\end{array}$ & $\begin{array}{l}79 \\
10\end{array}$ \\
\hline $\begin{array}{l}\text { Orativetska js } \\
\text { Orativetska p }\end{array}$ & $42^{*}$ & $\begin{array}{l}53 \\
35\end{array}$ & $\begin{array}{l}30 \\
27\end{array}$ & $\begin{array}{l}27 \\
27\end{array}$ & 43 & 20 & 17 \\
\hline Zhyvotivska js & - & 83 & 78 & 66 & 91 & 45 & 39 \\
\hline Starozhyvotivska js & - & 93 & 71 & 61 & - & 71 & 63 \\
\hline Novozhivotivska js & - & 71 & 49 & 38 & - & 34 & 30 \\
\hline Osichanska js & 97 & 85 & 61 & 52 & 84 & 27 & 26 \\
\hline Yushkovetska js & 104 & 70 & 49 & - & - & 117 & - \\
\hline Yakymivska js & $20^{*}$ & 56 & 43 & 26 & $44^{*}$ & 87 & 79 \\
\hline Medivska js & 105 & 80 & 66 & 8 & 84 & 52 & 43 \\
\hline Lopatynska js & - & 47 & 39 & 3 & 39 & 37 & 36 \\
\hline Frontivska js & 77 & 42 & 42 & 22 & - & 45 & 42 \\
\hline Chahivska js & $38^{*}$ & 85 & 75 & 58 & 67 & 42 & 40 \\
\hline Sologubivska js & $42^{*}$ & 78 & 69 & 37 & 103 & 58 & 54 \\
\hline Klyukivska js & - & 141 & 79 & 33 & - & 72 & 61 \\
\hline $\begin{array}{l}\text { Balabanivska js } \\
\text { Balabanivska p }\end{array}$ & 203 & $\begin{array}{c}95 \\
\text { Without 1sd } \\
\text { grade }\end{array}$ & $\begin{array}{l}80 \\
-\end{array}$ & $\begin{array}{l}52 \\
-\end{array}$ & 178 & $\begin{array}{l}64 \\
12\end{array}$ & $\begin{array}{l}60 \\
12\end{array}$ \\
\hline V. Rostivska js & 79 & 76 & 67 & 67 & - & 45 & 40 \\
\hline Zarudyanska hs & $47^{*}$ & 57 & 40 & 30 & 74 & 48 & 44 \\
\hline Pidvysochanska hs & 85 & 81 & 71 & 34 & 105 & 41 & 36 \\
\hline Mervynska p & $20^{*}$ & 40 & 33 & 30 & - & 30 & 25 \\
\hline Rozhychanska p & 59 & 48 & 27 & 27 & 59 & 15 & 12 \\
\hline Bugaivska p & - & 37 & 38 & 19 & 37 & 27 & 25 \\
\hline Kazymyrivska p & - & 25 & 21 & 15 & - & 24 & \\
\hline Honoratska p & - & 69 & 35 & 28 & 42 & 39 & 27 \\
\hline Kalenivska p & - & 40 & 30 & 14 & 18 & 29 & 25 \\
\hline Khmelivska p & - & 43 & 37 & 3 & - & 28 & 23 \\
\hline Stupchanska p & - & 12 & 9 & 8 & - & 27 & 27 \\
\hline Sabarivska p & - & 70 & 52 & 10 & 70 & 54 & 50 \\
\hline M. Rostivska p & - & 32 & 27 & 18 & 43 & 26 & 22 \\
\hline
\end{tabular}

Table 5. - Table of occupancy of first grades in Tarashchansky District of Kyiv region as of September 15, $1936^{31}$

\begin{tabular}{|l|c|c|c|}
\hline \multicolumn{1}{|c|}{ Name of the school } & Born in 1928 & $\begin{array}{c}\text { Came to 1st grade } \\
\text { In 1936 }\end{array}$ & Including 8-year-old \\
\hline Potochanska p & 40 & 36 & 22 \\
\hline Stanyshivska p & 54 & 20 & 24 \\
\hline Lisovytska p2 & 193 & 27 & 14 \\
$\begin{array}{l}\text { Lisovytska p3 } \\
\text { Lisovytska js }\end{array}$ & & 14 & 29 \\
\hline Kryvianska p & 40 & 58 & 20 \\
\hline Chervonoiarska p & 51 & 30 & 20 \\
\hline Makovetska p & & 23 & 17 \\
\hline Krasiuchanska p & - & 17 & - \\
\hline Antonivska p & - & & 15 \\
\hline Kosiakivska p & 94 & 31 & 24 \\
\hline Bovkunska p & 40 & 30 & 24 \\
\hline Krutohorbska p & 75 & 40 & 37 \\
\hline M. Berezianska p & 42 & 36 & 21 \\
\hline Rizhetska p & 147 & 31 & 29 \\
Rizhetska js & 40 & 36 & 30 \\
\hline Ulashivska p & 208 & 29 & 29 \\
\hline Luchanska p & & 64 & 56 \\
\hline Luchanska s & & 68 & 35 \\
\hline
\end{tabular}

su State Archives Of Vinnytsia Region. Fund P-6129. Desc. 13. File 105, 106, 107; State Archives of Kyiv Region. Fund P-144. Desc. 1. File 1880. Page 1-31; File 1688. Page 1-32.

${ }^{31}$ State Archives of Kyiv Region. Fund P-5634. Desc 1. File 1111, 1112, 1113, 1114, 1115, 1116, 1117, 1118, 1119, 1120, 1021, 1022, 1023, 1024; Fund P-144. Desc. 1. File 2060. Page 1 - 5; File 2066. Page $11-45$. 
Continuation of table 5

\begin{tabular}{|l|c|c|c|}
\hline \multicolumn{1}{|c|}{ Name of the school } & Born in 1928 & $\begin{array}{c}\text { Came to 1st grade } \\
\text { In 1936 }\end{array}$ & Including 8-year-old \\
\hline V. Berezianska js & 165 & 83 & 52 \\
\hline Kyslivska js & 65 & 48 & 18 \\
\hline $\begin{array}{l}\text { Kivshovatska js } \\
\text { Kivshovatska s }\end{array}$ & 203 & 87 & 43 \\
\hline Petrivska js & 137 & 52 & 50 \\
\hline Ploshchanska s & 78 & 54 & 41 \\
\hline Tarashchanska s1 & 323 & 39 & 36 \\
Tarashchanska s2 & & 51 & 34 \\
Tarashchanska p6 & 234 & 31 & 31 \\
\hline Zatonska s & 98 & 97 & 82 \\
\hline Chernynska js & 136 & 48 & 33 \\
\hline Severynivska js & 54 & 62 & 44 \\
\hline Dubivska s & 118 & 49 & 46 \\
\hline V. Vovnianska & - & 46 & 25 \\
\hline Yasynivska js & 42 & 36 & 30 \\
\hline Volodymyrivska js & 69 & 31 & 27 \\
\hline Kyrdanska js & 80 & 42 & 34 \\
\hline Lukianivska js & 61 & 46 & 39 \\
\hline Stepkivska js & 70 & 38 & 34 \\
\hline Veselokutska js & & 61 & 48 \\
\hline
\end{tabular}

Education of the UkrSSR, it turned out that there were 494,173 in the city and village, including 51 thousand from Dnipropetrovsk Region, data from which were not found in the report. ${ }^{32}$

This analysis (97 percent of the existing schools were developed) suggests that at least 287,000 of those born in 1930 did not live to see September 1, 1938. If we proceed from the calculations of the State Plan on the occupancy of 1st-4th grades in 1938, then this figure should have been $3,302,287$ students, and then only 1,971,658 could study. The difference is $1,330,629$ on average for the age group of 332,657 children!

A similar situation was with the age group of 1214 years, which at the beginning of 1933, according to the UNGO of the UkrSSR, amounted to 2,518.1 thousand children. Professor M. Ptukha then attributed 2,331.4 people to this group. ${ }^{33}$ According to the calculations of the State Plan, it was to consist of $2,230,733$ children in 1938 , and it turned out that there were only $1,414,551$ of them $-816,182$ less! On average for one year, the number of losses was 272,060 .
And together, these two age groups alone could lose at least more than 2 million children, given that 3 percent of schools are not included in the data.

And how will it look if we add the deaths of those born in 1931-1933? According to the surviving documents, there were many of them. For example, in the villages of Tarashchansky District of Kyiv Region, the losses of this age group reached 10 percent. In Ukraine, this number of losses can be estimated at several hundred thousand children, because a similar picture is found in the 19391940 school year in the Pereyaslav District of Kyiv Region (Table 6).

A similar situation developed in many other schools of the UkrSSR, as evidenced by documents found in the funds of the State Archives of Poltava Region, in particular, the fullness of primary grades since September 1, 1940, when the natives of 1932 first began studying. They turned out to be at least a third less than in the previous year, when the natives of 1931 came to school (Table 7).

Table 6. - Table of occupancy of first grades in Pereyaslav district of Kyiv Region in 1939-1940 school year ${ }^{34}$

\begin{tabular}{|l|c|c|c|}
\hline \multicolumn{1}{|c|}{ Name of the school } & Born in 1931 & $\begin{array}{c}\text { Came to 1st grade } \\
\text { in 1939 }\end{array}$ & Including 8-year-old \\
\hline Andrushi js & $\mathbf{3 5}$ & 18 & $\mathbf{1 1}$ \\
\hline Babachykha $p$ & $\mathbf{3 1}$ & 23 & $\mathbf{1 0}$ \\
\hline V. Karatul & - & 140 & 61 \\
\hline Vypovzky js & $\mathbf{5 4}$ & 14 & $\mathbf{1 2}$ \\
\hline Vinentsi js & $\mathbf{7 2}$ & 29 & $\mathbf{2 5}$ \\
\hline Vovchkiv js & $\mathbf{6 0}$ & 36 & $\mathbf{3 2}$ \\
\hline Voskresinka $\mathrm{30}$ & $\mathbf{3 6}$ & 19 & $\mathbf{1 9}$ \\
\hline Viunyshche js & $\mathbf{4 9}$ & 21 & $\mathbf{3 8}$ \\
\hline Haishyn js & $\mathbf{6 3}$ & 40 & $\mathbf{2 2}$ \\
\hline Hlanyshiv js & $\mathbf{5 1}$ & 37 & $\mathbf{1 0}$ \\
\hline Horodyshche $\mathrm{p}$ & $\mathbf{3 5}$ & 11 & $\mathbf{2 8}$ \\
\hline Hryhorivka js & - & 32 & $\mathbf{3 0}$ \\
\hline Demiantsi js & $\mathbf{8 5}$ & 35 & $\mathbf{4 2}$ \\
\hline Denysy js & $\mathbf{8 2}$ & 45 & \\
\hline
\end{tabular}

32 Ibid. Fund 2. Desc. 7. File 159. Page 179.

${ }^{33}$ Ibid. Fund 166. Desc. 10. File 1029. Page 50.

${ }^{34}$ State Archives of Kyiv Region. Fund 144. Desc. 1. File 2463. Page 1-52. 


\begin{tabular}{|c|c|c|c|}
\hline Name of the school & Born in 1931 & $\begin{array}{c}\text { Came to 1st grade } \\
\text { in } 1939\end{array}$ & Including 8-year-old \\
\hline Divychky js & 48 & 52 & 45 \\
\hline Yerkovtsi s & 100 & 76 & 59 \\
\hline Zarubentsi js & - & 35 & 21 \\
\hline Zasupoivka js & 48 & 38 & 28 \\
\hline Karan js & 64 & 14 & 10 \\
\hline Kovalyn js & 64 & 40 & 30 \\
\hline Kozyntsi js & 40 & 29 & 14 \\
\hline Kozliv js & 126 & 38 & 31 \\
\hline Komarivka js & 51 & 24 & 22 \\
\hline Kuliabivka js & 62 & 30 & 26 \\
\hline Letsky js & 52 & 27 & 24 \\
\hline Mazinky js & 33 & 35 & 33 \\
\hline M. Karatun $p$ & - & 30 & 20 \\
\hline Panfily js & 70 & 57 & 40 \\
\hline $\begin{array}{l}\text { Pereiaslav-1s } \\
\text { Pereiaslav-2s } \\
\text { Pereiaslav-3js }\end{array}$ & 210 & $\begin{array}{l}49 \\
95 \\
29 \\
\end{array}$ & $\begin{array}{l}41 \\
32 \\
29 \\
\end{array}$ \\
\hline Pidvarky js & 117 & & 77 \\
\hline Pidsinne $p$ & 36 & 22 & 20 \\
\hline Polozhai $p$ & 37 & 2 & 2 \\
\hline Polohy-Chobitky p & 230 & 9 & 7 \\
\hline Polohy-Verhuny js & 123 & 35 & 30 \\
\hline Polohy-Yanenky js & 188 & 22 & 22 \\
\hline Polohy-Yanenky js & & 54 & 27 \\
\hline Pomokli s & 179 & 68 & 59 \\
\hline Prystantsiina js & - & 37 & 35 \\
\hline Prystromy s & 90 & 62 & 53 \\
\hline Somkova Dolyna p & 29 & 19 & 17 \\
\hline Sosnova s & 97 & 51 & 47 \\
\hline Stovpiahy js & 46 & 31 & 28 \\
\hline Strokova s & 75 & 29 & 27 \\
\hline Studenyky s & 89 & 59 & 51 \\
\hline Tashan js & 60 & 30 & 23 \\
\hline Traktomyriv js & - & 26 & 20 \\
\hline Kharkivtsi js & 26 & 28 & 24 \\
\hline Khotsky s & 109 & 61 & 54 \\
\hline Tsybli js & 87 & 21 & 16 \\
\hline Shevchenkiv khut $p$ & - & 24 & 24 \\
\hline
\end{tabular}

Table 7. - Comparative table of the number of children born in 1931-1932 who became first-graders of some villages of Poltava Region in 1939 and 1940 (Serhiychuk, 2018: 335)

\begin{tabular}{|c|c|c|c|c|}
\hline Name of settlement, district & $\begin{array}{c}\text { Born in } \\
1931\end{array}$ & $\begin{array}{c}\text { Came to 1st grade } \\
\text { in } 1939\end{array}$ & $\begin{array}{c}\text { Born in } \\
1932\end{array}$ & $\begin{array}{c}\text { Came to 1st grade } \\
\text { in } 1940\end{array}$ \\
\hline 2. Velyka Krucha of Pyriatyn district & 48 & 26 & 32 & 20 \\
\hline 4. Zhdany of Chornukhyn district & 188 & 36 & 97 & 32 \\
\hline 5. Zarichchia of Pyriatyn district & 24 & 22 & 32 & 8 \\
\hline 6. Zasullya of Lokhvytsya district & 78 & 46 & 44 & 20 \\
\hline 9. Keibalivka of Pyriatyn district & 27 & 12 & 39 & 4 \\
\hline 10. Majorshyna of Pyriatyn district & 71 & 54 & 48 & 28 \\
\hline 11. Malyutyntsi of Pyriatyn district & 82 & 43 & 43 & 22 \\
\hline 12. Okip of Lubny district & 47 & 23 & 57 & 23 \\
\hline 13. Pyriatyn & 555 & 177 & 469 & 141 \\
\hline 18. Sukhonosivka of Chornukhyn district & 61 & 22 & 62 & 22 \\
\hline 19. Tarandents of Lubny district & 69 & 30 & 38 & 28 \\
\hline 20. Tarasivka of Pyriatyn district & 65 & 37 & 44 & 27 \\
\hline 21. Usivka of Pyriatyn district & 34 & 23 & 34 & 16 \\
\hline 22. Kharkiv residents of Pyriatyn district & $4^{*}$ & 31 & 50 & 37 \\
\hline 23. Khorishki of Lubny district & 65 & 39 & 44 & 21 \\
\hline 24. Chasnykivka of Lokhvytsya district & 70 & 27 & 40 & 20 \\
\hline 25. Sheky of Lubny district & 31 & 23 & 23 & 8 \\
\hline 26. Yatsyny of Pyriatyn district & 69 & 38 & 28 & 14 \\
\hline
\end{tabular}


The sharp decrease in the contingent of first-graders in schools of Poltava Region during these years is clearly indicated by the All-Union Census of 1939, especially natives of 1933, who had to begin studying in autumn 1941 - compared to those born in 1930 (that is, already somewhat strengthened in the three years since birth) they were almost three times less in the region (Table 8).

Table 8. - Contingent of first-graders in schools of Poltava Region in the distribution "City / Village" 35

\begin{tabular}{|c|c|c|c|}
\hline & City & Village & Total \\
\hline $1938-1939$ & 6.145 & 39.860 & 46.005 \\
\hline $1939-1940$ & 4.705 & 29.519 & 34.224 \\
\hline $1940-1941$ & 3.736 & 17.715 & 21.451 \\
\hline $1941-1942$ & 2.862 & 14.141 & 17.003 \\
\hline
\end{tabular}

As of December 30, 1940, there were 665,755 elementary school students in the 1st and 4th grades of schools in the eastern regions, 1,117,556 elementary school students and 840,038 middle school students, and a total of $2,623,349$ students. ${ }^{36}$ This is more than a million less than in the fall of 1932.

If we agree with the opinion of some demographers that the loss of children in 1932-1933 accounted for about a third of all victims of the Holodomor (our analysis of available evidence of death in 1933 in some villages gives a slightly higher figure: 38 percent), and they reach, as noted above, at least 4 million, it is easy to calculate the total amount of irreversible losses.

\section{Conclusions}

An analysis of the available statistics gives grounds to state the numbers of already established direct population losses of Holodomor genocide - at least 7 million people. At the same time, there were a lot more casualties of the Holodomor genocide. After all, according to calculations made through the occupancy of primary grades, only the loss of children amounted to at least 4 million since 1932. In total, there were more than 9 million victims in the UkrSSR. If we take into account the deaths of Ukrainians from the Holodomor outside its borders, it was more than 10 million casualties. This result is achieved through his- torical and legal research, which involves assessing the integrity of the scientist through investigative actions in accordance with the requirements of criminal procedure law.

\section{REFERENCES}

Dovidnyk z osnovnykh statystychno-ekonomichnykh pokaznykiv hospodarstva rayoniv Kyyivskoyi oblasty (1933). Kharkiv (In Ukrainian).

Holodomor 1932 - 1933 rokiv v Ukrayini (2007). Dokumenty i materialy. Vol. 2. Kyiv (In Ukrainian)

Holodomor v Ukrayini 1932 - 1933 rokiv (2008). Za dokumentamy politychnoho arkhivu Ministerstva zakordonnykh sprav Federatyvnoyi Respubliky Nimechchyny. Kyiv: Natsionalnyy instytut stratehichnykh doslidzhen. (In Ukrainian)

Horbachuk, V. (2010). Trydtsyat rokiv na Donbasi (shchodennykovi zapysy). 1973 - 2004. Slovyansk. (In Ukrainian)

Kovalenko, Lydia and Manyak, Volodymyr (1991). 33rd: Famine. People's Book-Memorial. Kyiv: Radyanskyy pys'mennyk (In Ukrainian)

Kulchytskyy, S. (1991). Tsina velykoho perelomu. Kyiv: Ukrayina. (In Ukrainian).

Levchuk, N.M. \& Boryak, T.G. \& Volovyna, K.V. \& Rudnytsky, O.P. \& Kovbasyuk, A.B. (2015). Losses of urban and rural population of Ukraine as a result of the Holodomor in 19321934: new estimates. Ukrainian Historical Journal. 4: 84-112. - http://resource.history.org.ua/publ/ UIJ _2015_4_7 (In Ukrainian)

Serhiychuk, V. (2018). Holodomor 1932 - 1933 rokiv yak henotsyd ukrayinstva. (Issue 2). Vyshhorod. (In Ukrainian)

Serhiychuk, V. (2020). V oboroni ukrayinskoyi pravdy (Issue 2). Vyshhorod. (In Ukrainian)

Serhiychuk, V. (2021, April, 14). Strashni tsyfry Holodomoru: chomu Hennadiy Yefimenko teper imenuye feykom svoye vidkryttya. Ukrayina moloda. https://www.umoloda.kiev.ua/number/3716/196/156246/ (In Ukrainian)

Tsaplin, V. (1989). Statistika zhertv stalinizma. Voprosy istorii, 4 (In Russian).

Volovyna, O. (2018, July, 13-14). Teror holodom: yak naukovo obhruntuvaty kilkist zhertv? Den (Kyiv) https://day.kyiv.ua/uk/article/poshta-dnya/teror-golodom-yaknaukovo-obgruntuvaty-kilkist-zhertv (In Ukrainian).

Zhiromskaya, V. (2001). Demograficheskaya istoriya Rossii v 1930-e gody. Vzglyad $v$ neizvestnoye. Moscow: ROSSPEN. (In Russian)

\section{Володимир Сергійчук,}

Київський начіональний університет імені Тараса Шевченка (м. Київ, Украӥна)

e-mail: serhijchuk@ukr.net, ORCID 0000-0002-4053-1733

\section{ВСТАНОВЛЕННЯ КІЛЬКОСТІ ЖЕРТВ ГОЛОДОМОРУ-ГЕНОЦИДУ 1932 - 1933 РОКІВ В УКРАЇНІ}

У статті проаналізовано стан підрахунку жертв Голодомору-геноциду 1932 - 1933 років в Україні. Зокрема наводяться свідчення тогочасних німецьких та італійських дипломатів, які одержували конфіденційну інформацію від радянських урядовців, яка і лягла в основу усталеного в діаспорі виразу про втрати: «від 7 до 10 мільйонів». Наголошується, що в ході горбачовської перебудови в СРСР Москва змушена була визнати Голодомор в Україні й дозволила писати про втрати від нього в кількості 3,5 мільйона осіб.

\footnotetext{
35 State Archives of Poltava Region. Fund P-3938. Desc. 1. File 319. Page 14.

${ }^{36}$ The Central State Archives of Supreme Bodies of Power and Government of Ukraine. Fund 318. Desc. 1. File 1370. Page $4-6$.
} 
Цю цифру продовжують обстоювати 3 деякими уточненнями й сучасні українські демографи, котрі працюють на закордонні гранти. У той же час первинні документи українських архівів завдяки історикостатистичному методу дають можливість встановити мінімальну кількість втрат під час Голодоморугеноциду 1932 - 1933 років у 7.117,6 тисячі осіб, бо збереглися дані про кіль-кість населення УСРР станом на початок 1932 року в кількості 32,680 тисяч осіб і про народжених у 1932 - 1933 роках, що дає можливість, використовуючи уточнені матеріали Всесоюзного перепису 1937 року й людський приріст у 1934 1936 роках, встановити наявність мешканців міста й села станом на 1 січня 1934 року - лише 26.815,8 тисячі. А мало бути - 33.853,5 тисячі. А використання історико-статистичного методу розрахунків дозволяє вийти і на показник 9,5 мільйона в УСРР. Це за умови, коли будуть пораховані померлі голодні українські селяни в Росії та Білорусі, куди вони пішли за хлібом, і розстріляні радянськими прикордонниками чи потоплені в Збручі й Дністрі через невміння плавати; коли буде встановлено кількість завезених у 1932 1936 роках заробітчан з радянських республік на соціалістичні новобудови УСРР, яких під час Всесоюзного перепису 1937 року порахують як їі мешканців тощо.

Особливе значення для встановлення вірогідності цих втрат має реконструкція відповідності наповнення пер-ших класів українських шкіл у 1932 - 1939 роках з кількістю народжених у 1924 - 1931 роках. Так, у Оратівському, Таращанському й Переяславському районах тодішньої Київської області після 1933 року до них прийняли поло-вину, а то й менше дітей 8-річного віку, які тоді йшли до школи. Така ж картина і по всіх районах нинішньої Полта-вської області. Як і в усіх початкових школах Петриківського району Дніпропетровської області, де з минулорічних учнів 1-3 класів, хто продовжив навчання 31 вересня 1933 року, не дорахувалися 1.883 - майже половини.

Саме такий комплексний підхід дослідження дає можливість встановити втрати дітей мінімум до 4 мільйонів, а загальні по УСРР з використанням історико-правового методу - понад 9 мільйонів осіб. До цих жертв необхідно додати і понад 1 мільйон втрат українців поза межами УСРР, що становить у цілому понад 10 мільйонів.

Ключові слова: Голодомор-геноцид українців у 1932-1933 роках; історико-статистичні підрахунки і демографрічні розрахунки реальних втрат.

(C) Volodymyr Serhiychuk

Надійшла до редакції: 14.07.2021

Прийнята до друку: 30.07.2021 